DOI 10.22460/infinity.v7i2.p123-132

\title{
THE STUDENTS' MATHEMATICAL ABSTRACTION ABILITY THROUGH REALISTIC MATHEMATICS EDUCATION WITH VBA-MICROSOFT EXCEL
}

\author{
Nelly Fitriani ${ }^{1}$, Didi Suryadi ${ }^{2}$ Darhim $^{3}$ \\ ${ }^{1,2,3}$ Universitas Pendidikan Indonesia, Jl. Setiabudhi No. 229, Isola, Sukasari, Bandung, Indonesia \\ ${ }^{1}$ nellyfitriani@ @student.upi.edu, ${ }^{2}$ ddsuryadi1@gmail.com, ${ }^{3}$ darhim_55@yahoo.com
}

Received: June 30, 2018 ; Accepted: August 30, 2018

\begin{abstract}
The purpose of this research is to analyze the level of abstraction mathematical ability of the students through learning using Realistic Mathematics Education (RME) with Visual Basic Application (VBA) for Microsoft Excel. This research uses a descriptive qualitative method and the subject of this study is junior high school students of grade $9^{\text {th }}$ in one school in Ngamprah as many as 35 students. One of the instruments in this study is the abstraction test. Results show that as many as $65.71 \%$ of students are in the first level of Perceptual Abstraction. As many as 57.14\% of students are in the second level of Internalization. As many as $31.43 \%$ of students are in the third level of Interiorization, and as many as $17.14 \%$ of students are at the last level, namely Second Level of Interiorization. Overall, the sample in this study can be categorized into four levels of abstraction.
\end{abstract}

Keywords: Mathematical Abstraction, Realistic Mathematics Education, Visual Basic Application for Microsoft Excel.

\begin{abstract}
Abstrak
Tujuan penelitian ini adalah untuk menganalisis kemampuan abstraksi matematis siswa berdasarkan level abstraksinya melalui pembelajaran dengan menggunakan pendekatan Realistic Mathematics Education (RME) berbantuan Visual Basic Application (VBA). Penelitian ini menggunakan metode kualitatif deskriptif dengan subjek penelitiannya adalah siswa SMP kelas IX di Ngamprah sebanyak 35 siswa. Instrumen dalam penelitian ini diantaranya adalah soal tes abstraksi. Hasil yang diperoleh menunjukkan bahwa sebanyak $65,71 \%$ siswa sudah ada pada level pertama yaitu Perceptual Abstraction. Sebanyak $57,14 \%$ siswa sudah ada pada level kedua yaitu Internalization. Sebanyak $31,43 \%$ siswa sudah berada pada level ketiga yaitu Interiorization dan sebanyak $17,14 \%$ siswa sudah berada pada level terakhir yaitu Second Level of Interiorization. Secara keseluruhan, sampel dalam penelitian ini dapat dikategorikan ke dalam empat level abstraksi.
\end{abstract}

Kata Kunci: Abstraksi Matematis, Realistic Mathematics Education, Visual Basic Application for Microsoft Excel.

How to Cite: Fitriani, N., Suryadi, D., \& Darhim, D. (2018). The Students' Mathematical Abstraction Ability through Realistic Mathematics Education with VBA-Microsoft Excel. Infinity, 7(2), 123-132. doi:10.22460/infinity.v7i2.p123-132. 


\section{INTRODUCTION}

Concepts in mathematics are abstract (including geometry). Students will have difficulty if they are emphasized to memorize. Concepts should be constructed in the minds of students and not transferred by the teacher to students directly.

The concept construction process that occurs in the minds of students by utilizing their initial experience or knowledge is called the process of mathematical abstraction (Nurhasanah, Kusumah, Sabandar, \& Suryadi, 2017). In line with this, process of abstraction occurs when a person realizes the similarity of characteristics between objects based on experience that already happens (Skemp, 2012). These similarities are used as a basis for classification so that one can recognize a new experience by comparing it with experiences already established in the previous thought. This process is called the process of abstraction. The result of the abstraction process is a concept.

Based on the above definition, the process of abstraction will exist through one's experiences, i.e. the student's experience in constructing an initial mathematical knowledge and the concept. Here, the concept in mathematics feels very meaningful, because the concepts are interrelated and mutually required. So, it is essential for students to master the process of abstraction.

Some experts who have reviewed the issue and in general, previous studies were still on topics outside of geometry (Ferrari, 2003). The process of abstraction has a vital role in Geometry learning (Mitchelmore \& White, 2007). However, from a cognitive point of view, abstraction is one of the reasons for failure in mathematics, including geometry (Ferrari, 2003). In Indonesia, Geometry becomes one part of the mathematics material of the school where students experience many problems. It is in line with the results of Trends in International Mathematics and Science Study (TIMSS) in 2011 which conveyed that the dimension of Indonesian students' lowest content is geometry.

The failure is allegedly related to the way to form abstract mathematical objects. The formation cannot be done only through the delivery of information directly but requires an object forming process through a series of experiences directly by students. So it becomes something interesting to examine students' abstraction in understanding geometry.

There are several ways that abstractions may arise in learning, namely: Familiarize students to find relevant contexts; Direct students to recognize commonalities across contexts; Make students feel the same so they can form a universal concept; Direct students to apply the concept in new situations (Mitchelmore \& White, 2007). Based on the above, a learning design that can facilitate the abstraction process is using VBA-assisted RME approach.

The RME approach designed to direct students to find relevant contexts early in the learning process (Fitriani, 2015). Then with the help of VBA, students are directed to recognize the similarities of the properties contained in the concept of tubes and circles. The programming language in VBA produces a dynamic view of the system. The volume of the constructed tube is the sum of the area of the circle multiplied by its thickness. Students will form a universal concept in a new situation. Besides, RME is applied because it has the main characteristics of a self-developed model. It greatly facilitates the occurrence of mathematical abstraction processes. Self-developed models can bridge the gulf between informal and formal knowledge in mathematics. Students build their knowledge gradually from the knowledge 
they possess as a result of their interaction with the environment, enhanced toward a semiconcrete form, then move into semi-abstract and abstract. It greatly facilitates the process of abstraction. Thus, it is possible that the RME approach is applied to train students to produce a mathematical abstraction process.

\section{Mathematical Abstraction}

Piaget (Gray, 2007) distinguishes three kinds of abstractions, namely, Empirical Abstraction, Pseudo-Empirical Abstraction, and Abstraction Reflective. Empirical Abstraction states that knowledge comes from experiences. Pseudo-Empirical Abstraction is between Empirical and Reflective Abstraction. It occurs when the subject is confronted with an object and then finds the properties of the object through the process of imagining an action on the object. Piaget describes abstraction Reflective as the general coordination of action in such a way that the source is a subject equipped with a full internal nature.

Abstractions divided into empirical and theoretical abstractions (Mitchelmore \& White, 2007). Theoretical abstraction consists of forming concepts that correspond to several theories. A clear example of the difference between empirical and theoretical abstractions is: When studying the concept of a tube, according to an empirical abstraction the process is that students recognize the various forms of representation of the tube first, as are examples of the forms of the tubes in everyday life. Students will recognize the same characteristics based on experiences with real objects. From various contexts, it will introduce a concept. In a theoretical abstraction, the teacher introduces the students to the concept and definition of a prism. After that, students are led to conclude that the tube is a unique prism. It is useful for students to come up with a generalization process based on the relationship between the two concepts. From these examples, there is a difference between the two abstractions. In empirical abstraction, individuals form new concepts based on observation and experience. While in theoretical abstraction, new concepts will emerge by matching existing concepts with experiences that have already been formed and stored first in individual thought. Piaget's theory of reflective abstraction is in the category of theoretical abstraction.

In this study, the focus is on empirical and reflective abstractions. Based on the characteristics of the two types of abstraction, the empirical abstractions appear before a reflective abstraction. To coordinate and reorganize (collect, arrange, develop) mental actions, one must first recognize the same characteristics of an object, then analyze its association with the existing knowledge (Nurhasanah, 2018).

\section{Visual Basic Application for Microsoft Excel}

Visual Basic Application (VBA) for Microsoft Excel is a data processing and numeric software that automatically utilizes mathematical functions using the help of Visual Basic codes. The advantages of Microsoft Excel are the use of mathematical functions associated with daily life such as financial, statistics, engineering, information and the Web. Besides, the software has many different shapes and images of type and size. However, the relationship between mathematical functions and images, cannot run correctly when not using VBA for Microsoft Excel. With the visual basic, the images in Microsoft Excel become interactive by connecting the mathematical functions in the form of the code language. VBA for Excel can create automated commands to run programs on mathematical arithmetic operations associated with images as a mathematical medium (Chotimah, Bernard, \& Wulandari, 2018). Utilization of ICT-based media can provide students with a more useful understanding of audio-visual by utilizing image features in mathematics learning (Bernard, 2015). The use of 
VBA for Excel in mathematics learning media is an effort to improve the ability of mathematical thinking and student activeness because of the interactive images.

\section{METHOD}

This research uses a descriptive qualitative method and the subject of this study is junior high school students of grade $9^{\text {th }}$ in one school in Ngamprah as many as 35 students. The main instruments in this research are mathematics abstraction ability test. This is an example of an instrument to measure the level of students' mathematical abstraction ability in level 2,

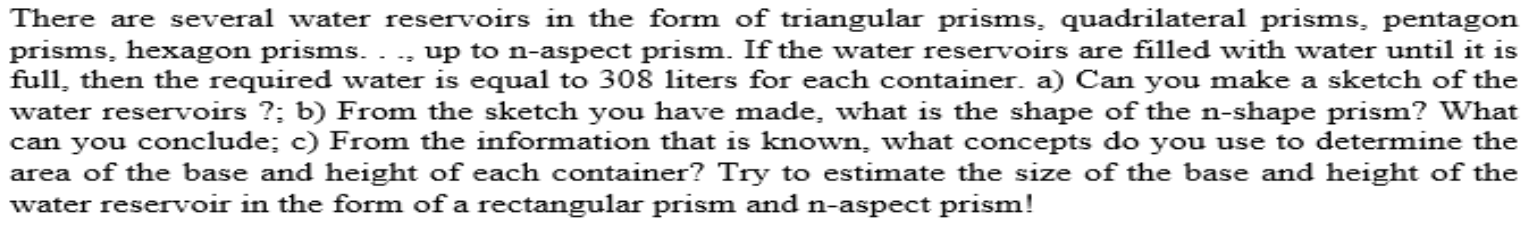
water reservoirs?; b) From the sketch you have made, what is the shape of the n-shape prism? What can you conclude; c) From the information that is known, what concepts do you use to determine the area of the base and height of each container? Try to estimate the size of the base and height of the water reservoir in the form of a rectangular prism and n-aspect prism!

\section{Figure 1. Sample Abstraction Test Questions}

Researchers want to analyze in depth the abstraction abilities of mathematical students based on abstraction level through learning by using RME approach through VBA. The research question is: What is the level abilities of students' mathematical abstraction in the class using Realistic Mathematics Education (RME) approach with Visual Basic Application (VBA) for Microsoft Excel.

\section{RESULTS AND DISCUSSION}

The mathematical thinking process based on the RME approach assisted by VBA Excel helps students bridge the horizontal mathematization process towards vertical mathematization mathematical formations. Through this, the process of abstraction do well, and learning becomes more meaningful. Furthermore, to detect abstractions that occur in learning, then we must arrange the indicator. This study modifies indicators for abstraction level abilities. This indicator is for analyzing abstraction levels in junior high school students (Hong \& Kim, 2016; Nurhasanah, 2018),

Tabel 1. Indicator of Mathematical Abstraction Level

\begin{tabular}{ll}
$\begin{array}{c}\text { Mathematical } \\
\text { Abstraction Level }\end{array}$ & \multicolumn{1}{c}{ Indicator } \\
\hline Perceptual Abstraction & a. $\begin{array}{l}\text { Know the properties of mathematical objects based } \\
\text { on the utilization of physical objects. } \\
\text { b. Recognise previous experience related to the problem } \\
\text { at hand. }\end{array}$ \\
Internalization & a. $\begin{array}{l}\text { Represents the results of thought in the form of } \\
\text { mathematical symbols, words or diagrams. }\end{array}$ \\
Interiorization & b. Able to resolve/manipulate the problem. \\
& $\begin{array}{l}\text { Reorganize (collect, organise, develop, coordinate) } \\
\text { concepts into new understandings or new knowledge. }\end{array}$ \\
Second Level of & Generalize new knowledge in different contexts. \\
Interiorization &
\end{tabular}


The student's abstraction level in solving problems related to the concept of the curved-face three-dimensional objects will be described in Table 2 below,

Table 2. Results of Data Analysis on Abstraction Level

\begin{tabular}{|c|c|c|c|}
\hline Answer Characteristics & $\begin{array}{c}\text { Level of } \\
\text { Abstraction }\end{array}$ & $\begin{array}{l}\text { Number of } \\
\text { Participants }\end{array}$ & $\begin{array}{c}\text { Percentage } \\
\%\end{array}$ \\
\hline $\begin{array}{l}\text { Students recognize the properties of the } \\
\text { tube by utilizing the image of its nets. } \\
\text { Based on the image, students can } \\
\text { imagine the surface area of the tube. } \\
\text { Students recall the previous experience } \\
\text { of the circumference of the circle with } \\
\text { the size of the radius of } 14 \mathrm{~cm} \text { and the } \\
\text { definition of the rectangle (the DC length } \\
\text { is equal to AB and parallel, i.e., } 88 \mathrm{~cm} \text { ), } \\
\text { so the student can deduce that the nets } \\
\text { can form a tube or not. Students must } \\
\text { conclude that ABCD is a square. Then } \\
\text { students can also conclude that the } \\
\text { circumference of a circle with DC or AB } \\
\text { length, is the same length. Thus, the nets } \\
\text { can form a tube. }\end{array}$ & $\begin{array}{l}\text { Perceptual } \\
\text { Abstraction }\end{array}$ & 23 & 65.71 \\
\hline $\begin{array}{l}\text { Students can represent the results of their } \\
\text { thinking by sketching the image of a } \\
\text { quadrilateral prism, pentagon, hexagon, } \\
\text { and n sides. With the image, the students } \\
\text { can construct the concept of a tube (a } \\
\text { tube is a unique prism with a base and } \\
\text { roof is n sides or a circle). Students will } \\
\text { realize that the tube is a unique prism, so } \\
\text { to determine its volume, they use a } \\
\text { similar formula, only adapted to the base } \\
\text { form. The student can solve the problem } \\
\text { because he can deduce the formula of the } \\
\text { tube. }\end{array}$ & Internalization & 20 & 57.14 \\
\hline $\begin{array}{l}\text { Students can gather information on the } \\
\text { issue. He was able to conclude that the } \\
\text { object contained in the problem is a } \\
\text { truncated cone. On the problem, it is not } \\
\text { required to sketch, but the student can } \\
\text { sketch it. Then, he was able to coordinate } \\
\text { the concept of Value Comparison and } \\
\text { Phytagoras concept in solving the } \\
\text { problem. A direct proportion concept is } \\
\text { used to determine the length of the } \\
\text { painter's line }(S) \text { on the lower cone. As a } \\
\text { result, } S=10 \mathrm{~cm} \text {. The Pythagoras }\end{array}$ & Interiorization & 11 & 31.43 \\
\hline
\end{tabular}




\begin{tabular}{|c|c|c|c|}
\hline Answer Characteristics & $\begin{array}{c}\text { Level of } \\
\text { Abstraction }\end{array}$ & $\begin{array}{c}\text { Number of } \\
\text { Participants }\end{array}$ & $\begin{array}{c}\text { Percentage } \\
\%\end{array}$ \\
\hline $\begin{array}{l}\text { concept is used to determine the height } \\
\text { of a small cone, which is } 8 \mathrm{~cm} \text {, and the } \\
\text { height of a large cone, which is } 18 \mathrm{~cm} \text {. } \\
\text { After all the data is complete, then he can } \\
\text { determine the truncated cone volume, by } \\
\text { calculating the difference between the } \\
\text { full cone and the small cone at the } \\
\text { bottom. }\end{array}$ & & & \\
\hline $\begin{array}{l}\text { Students can recall the concept of } \\
\text { pyramid volume. They can sketch the } \\
\text { pyramid even its not asked in the } \\
\text { problem. They generalized that a tiny } \\
\text { collection of pyramids would form a } \\
\text { solid ball through proof of the sum of } \\
\text { pyramid volumes of n pyramid. If the } \\
\text { formula is simplified, it will form a } \\
\text { formula } \\
\frac{1}{3} \times \boldsymbol{r} \times \text { a surface area of the ball. } \\
\text { After generalizing the ball volume } \\
\text { formula based on the number of pyramid } \\
\text { volumes of n pieces, the student can } \\
\text { solve the problem that the ball volume is } \\
36 \mathrm{~cm}^{2} \text {. }\end{array}$ & $\begin{array}{l}\text { Second Level } \\
\text { of } \\
\text { Interiorization }\end{array}$ & 6 & 17.14 \\
\hline
\end{tabular}

Based on the theory of abstraction levels, the results of the student work analysis show that some students have met all types of abstraction levels (Hong \& Kim, 2016; Nurhasanah, 2018). As many as $65.71 \%$ of students already in the first level, namely Perceptual Abstraction. Student errors occur when they can not recognize the concept of the circumference of the circle. Students cannot argue that the circumference of the circle should be as large as the length of $\mathrm{AB}$ or $\mathrm{CD}$. As many as $57.14 \%$ of students already exist in the second level, namely Internalization. Student errors occur when they can not sketch the prisms. They are unable to generalize the tube which is a unique prism and cannot solve the problem. A total of $31.43 \%$ of students are already in the third level, namely Interiorization. Student errors occur when they can not conclude that the object is a cone cut off, they conclude that the object is a tube, so the solution to the problem was not appropriate. A total of $17.14 \%$ of students are already in the fourth level, namely Second Level of Interiorization. Student errors occur when they can not generalize new knowledge to the concept of the pyramid in the context of a sphere.

The following will describe the results of interviews and student work results for the given abstraction test.

$\mathrm{G} \quad$ : Can images of these nets form a tube build?

$\mathrm{S} 1$ : yes I can, because based on the information given on the problem, it is known that the $D C$ length is the same length and parallel to the $A B$, and the circumference of the base is the same as the length of the $D C$ or $A B$.

$\mathrm{S} 2$ : maybe 
S2 : Same with you, I'm also the answer

$\mathrm{G} \quad$ : to determine the area of the base and height of the prisms, what concept do you use?

$\mathrm{S} 1$ : prism volume

$\mathrm{G} \quad$ : can you determine the volume of a rectangular prism?

$\mathrm{S} 1$ : yes i can ma'am

$\mathrm{G} \quad$ : prism in terms of $n$ ?

$\mathrm{S} 1$ : (silent), because it has the same properties as all, the n-prism of the volume must be the same

$\mathrm{G} \quad$ : what distinguishes it?

S1 : depending on the shape of the base or roof

Based on clinical interviews conducted, it appears that S1 is already on the second level, Internalization, while the S2 has not yet reached this level. S2 errors occur when they cannot make sketches of the prisms, so he is unable to make a generalization about the tube which is a special prism and so in solving the problem.

For the level of interiorization, only 11 students experienced it. In general, students are not able to reorganize (collect, compile, develop, coordinate) concepts into new understanding or new knowledge (Nurhasanah, 2018). Students cannot conclude that the building presented is a building from a hollow cone, they are more of a view that the building is a tube so that the solution becomes very inappropriate. likewise for the second level of interiorization, only a few have achieved it. students still find it difficult to generalize new knowledge in different contexts, students tend to be able to solve problems for similar contexts. Overall, based on the action taken has made the student abstraction process appear, and the sample in this study can be categorized into four levels of abstraction.

\section{CONCLUSION}

Based on the learning that has been done to 35 sample students, some students are appropriate for all types of abstraction levels. As many as $65.71 \%$ of students are in the first level (Perceptual Abstraction). As many as 57.14\% of students are in the second level (Internalization). As many as $31.43 \%$ of students are in the third level (Interiorization), and $17.14 \%$ of students are at the last level (Second Level of Interiorization). Overall, the sample in this study can be categorized into four levels of abstraction.

\section{ACKNOWLEDGMENTS}

Thanks to Technology Research and High Education Ministry for providing doctoral dissertation research grant, so the researcher can conduct this study to accelerate the completion of her study of the doctorate program and thanks to many people who have helped in completing this research, especially to Mrs. Farida Nurhasanah, because she is very helpful in directing writers when experiencing a deadlock.

\section{REFERENCES}

Bernard, M. (2015). Meningkatkan Kemampuan Komunikasi dan Penalaran serta Disposisi Matematik untuk Siswa SMP dengan Pendekatan RME. Infinity, 4(2), 197-222.

Chotimah, S., Bernard, M., \& Wulandari, S. M. (2018). Contextual approach using VBA learning media to improve students mathematical displacement and disposition ability Contextual approach using VBA learning media to improve students , 
mathematical displacement and disposition ability. Journal of Physics: Conf. Series, 948(1), 1-10.

Ferrari, P. L. (2003). Abstraction in mathematicso Title. The Royal Society, 358, 1225-1230.

Fitriani, N. (2015). Hubungan antara Kemampuan Pemecahan Masalah Matematis dengan Self Confidence Siswa SMP yang Menggunakan Pendekatan Pendidikan Matematika Realistik. Jurnal Euclid, 2(2), 341-351.

Gray, E. (2007). Abstraction as a Natural Process of Mental Compression. Mathematics Education Research Journal, 19(2), 23-40.

Hong, J. Y., \& Kim, M. K. (2016). Mathematical abstraction in the solving of ill-structured problems by elementary school students in Korea. Eurasia Journal of Mathematics, Science and Technology Education, 12(2), 267-281. https://doi.org/10.12973/eurasia.2016.1204a

Jones, K. D. (2010). The Unstructured Clinical Interview. Journal of Counseling \& Development Development, 88, 220-227. https://doi.org/doi:10.1002/j.15566678.2010.tb00013.x

Mitchelmore, M. C., \& White, P. (2007). Abstraction in mathematics learning. Mathematics Education Research Journal, 19(2), 1-9. https://doi.org/10.1007/BF03217452

Nurhasanah, F. (2018). mathematical abstraction of pre-service mathematics teacher in learning non- conventional mathematics consepts. Universitas Pendidikan Indonesia.

Nurhasanah, F., Kusumah, Y. S., Sabandar, J., \& Suryadi, D. (2017). Mathematical Abstraction: Constructing Concept of Parallel Coordinates. Journal of Physics: Conference Series, 895(1), 012076. https://doi.org/10.1088/1742-6596/895/1/012076

Skemp, R. R. (2012). The psychology of learning mathematics: Expanded American edition. New York: Routledge.

van Oers, B., \& Poland, M. (2007). Schematising activities as a means for encouraging young children to think abstractly. Mathematics Education Research Journal, 19(2), 10-22. https://doi.org/10.1007/BF03217453 
132 Fitriani, Suryadi, \& Darhim, The Students' Mathematical Abstraction Ability through ... 